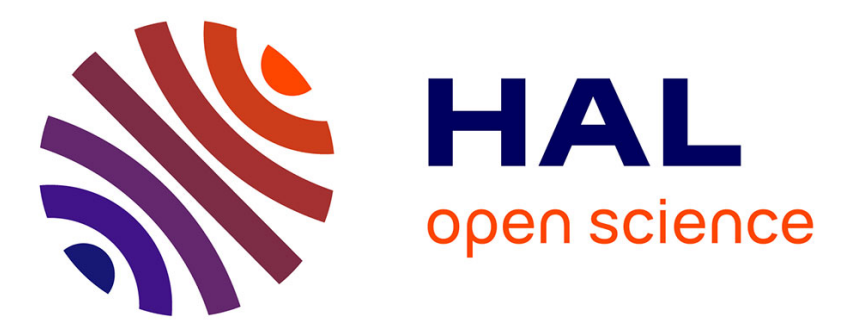

\title{
The Saint-Georges-sur-Loire olistostrome, a key zone to understand the Gondwana-Armorica boundary in the Variscan belt (Southern Brittany, France).
}

\author{
Carine Cartier, Michel Faure
}

\section{To cite this version:}

Carine Cartier, Michel Faure. The Saint-Georges-sur-Loire olistostrome, a key zone to understand the Gondwana-Armorica boundary in the Variscan belt (Southern Brittany, France).. International Journal of Earth Sciences, 2004, 93, pp.6, 945-958. 10.1007/s00531-004-0398-3 . hal-00068289

HAL Id: hal-00068289

https://hal-insu.archives-ouvertes.fr/hal-00068289

Submitted on 13 Nov 2006

HAL is a multi-disciplinary open access archive for the deposit and dissemination of scientific research documents, whether they are published or not. The documents may come from teaching and research institutions in France or abroad, or from public or private research centers.
L'archive ouverte pluridisciplinaire $\mathbf{H A L}$, est destinée au dépôt et à la diffusion de documents scientifiques de niveau recherche, publiés ou non, émanant des établissements d'enseignement et de recherche français ou étrangers, des laboratoires publics ou privés. 


\title{
The Saint-Georges-sur-Loire olistostrome, a key zone to understand the Gondwana-Armorica boundary in the Variscan belt (Southern Brittany, France)
}

\author{
Carine Cartier $^{1}$ and Michel Faure ${ }^{1}$ \\ 1 Institut des Sciences de la Terre d'Orléans (ISTO) UMR CNRS 6113, Bâtiment \\ Géosciences, BP 6759, 45067 Orléans Cedex 2, France
}

\begin{abstract}
In the southern part of the French Armorican massif, the Ligerian domain is located along the boundary between Gondwana and Armorica. Lithological, geochemical and structural data on the Saint-Georges-sur-Loire Unit, which is the northern part of the Ligerian domain, allow us to distinguish two sub-units. A southern sub-unit, formed by various blocks (chert, limestone, sandstone, rhyolite, mafic rocks) of Silurian to Middle Devonian age included as olistoliths in a Middle-Late Devonian terrigeneous matrix, overthrusts a sandstone-pelite northern sub-unit. Both units experienced two deformation events. The first one is a top-to-the-NW thrusting and the second one is a left-lateral wrenching. The Saint-Georges-sur-Loire Unit is an accretionary prism formed during the Late Devonian closure of the Layon rift, coeval with the main phase of the Variscan orogeny. The Layon rift, which according to the mafic olistoliths was partly floored by oceanic crust, appears as a buffer structural zone that accounts for the lack in Central Brittany of any tectonic or sedimentary echo of the closure of the MedioEuropean Ocean. The tectonic evolution of the Saint-Georges-sur-Loire Unit supports a polyorogenic model for this part of the Variscan Belt.
\end{abstract}

Keywords Paleozoic - Variscan - Armorican massif - Geodynamic - Saint-Georges-sur-Loire Unit 


\section{Introduction}

The West European Variscan Belt results of the collision of two main continental masses, Gondwana to the South and Laurussia to the North and several intervening microcontinents such as Avalonia or Armorica (e. g. Matte, 2001). However, the reality of Armorica is questioned by some authors (e. g. Paris and Robardet, 1990; Robardet, 2003 and enclosed references). In France, the boundary between Gondwana and Armorica is directly exposed in the southern part of the Armorican massif, along the Ligerian domain (Cogné, 1977; Fig. 1a). Therefore, the Ligerian domain appears as a key area to study the relationships between these two continental masses. Amongst the different structural units constituting the Ligerian domain, the northern one, called the Saint-Georges-sur-Loire Unit is poorly investigated. This paper deals with the lithology, geochemistry and structure of the Saint-Georges-sur-Loire Unit. Those results are used to discuss a possible geodynamic evolution for the Ligerian domain during Paleozoic times.

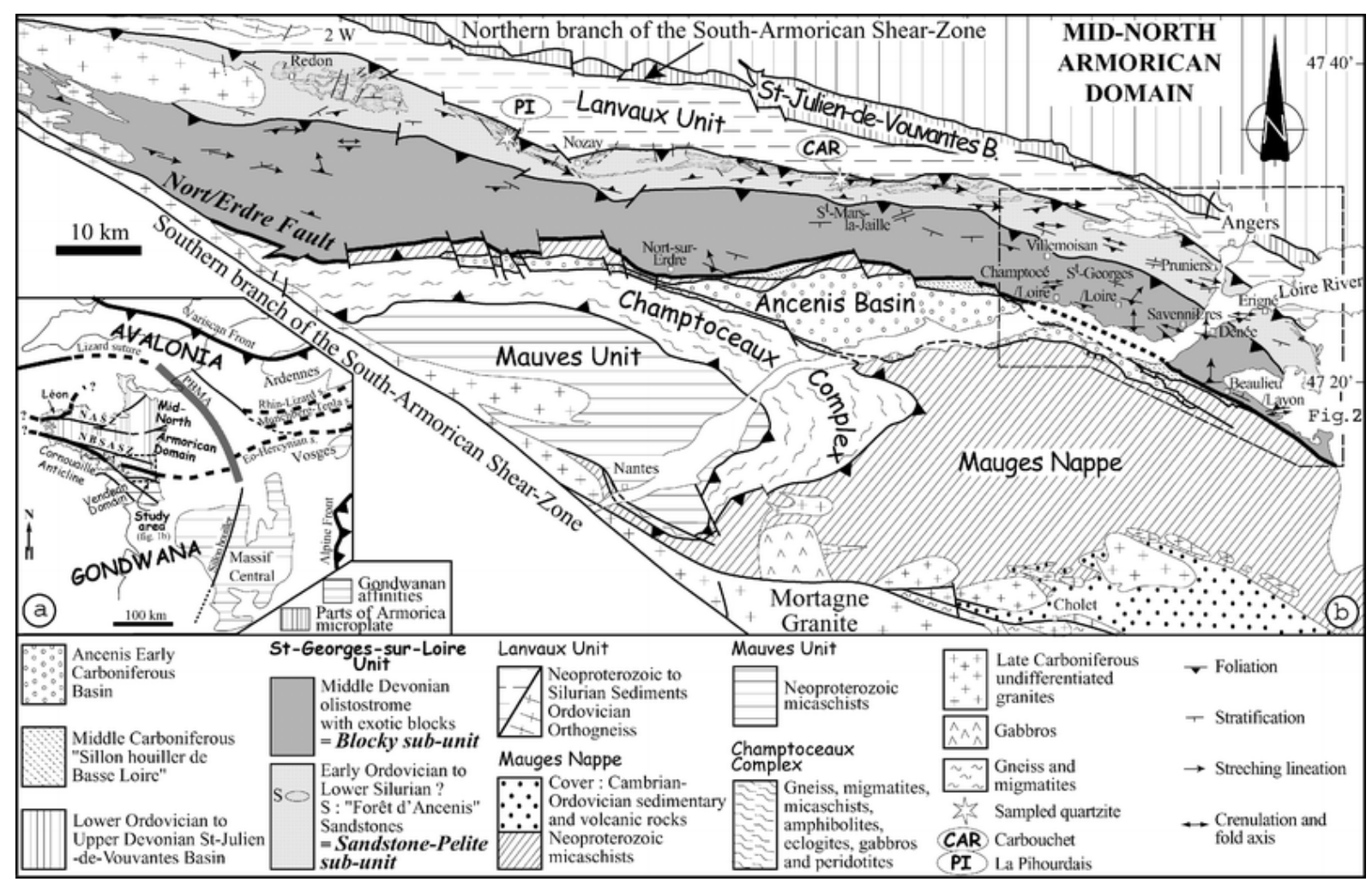

Fig. 1a, b a: Location of the study area and the Armorican massif in the tectonic framework of the Variscan Belt of Western Europe. b: Structural map of the Ligerian domain showing the study area of Fig. 2

\section{Geological setting}

\section{The Ligerian domain in the Armorican massif}

The WNW-ESE structural trend of the Armorican massif is controlled by crustal- or lithospheric-scale subvertical faults (Bitri et al., 2003). The northern and southern branches of the South-Armorican Shear-Zone divide the Armorican massif into the Mid-North Armorican, Ligerian and South Armorican domains from North to South (Fig. 1a; e.g. Cogné, 1977; Paris 
and Robardet 1990). However, this structural subdivision does not take into account sedimentary and paleogeographic features.

The Ligerian domain is a composite domain which must be separated into two distinct zones (Fig. 1b, Diot and Blaise, 1978), namely:

- a northern sub-domain including from North to South the Saint-Julien-de-Vouvantes Unit, The Lanvaux Unit and the Saint-Georges-sur-Loire Unit,

- a southern sub-domain made of a stack of nappes, from NW to SE and bottom to top: the Mauves Unit or para-autochthonous basement, the Champtoceaux high-pressure nappes complex and the overlying Mauges basement nappe.

The Ancenis basin was opened in the Mauges Nappe during Early Carboniferous and the Sillon Houiller de Basse Loire" is a Namurian coal basin. The Nort-sur-Erdre fault that separates these two sub-domains is a major tectonic and paleogeographic boundary corresponding here to the suture zone between Gondwana and Armorica (e.g. Faure et al., 1997; Cartier et al., 2001).

\section{The Saint-Georges-sur-Loire Unit}

The Saint-Georges-sur-Loire Unit is limited to the North by a northward thrust over the Lanvaux Unit, to the South by the Nort-sur-Erdre fault, to the West by the Southern branch of the South-Armorican Shear-Zone, and to the East, the Saint-Georges-sur-Loire Unit disappears under the Paris basin Mesozoic cover (Figs. 1a, 1b, Ledru et al., 1986). This unit is divided into two sub-units, namely i) a northern sub-unit called "the Sandstone-Pelite subunit ${ }^{n}$ with coherent terrigeneous rocks and devoid of volcanic rocks; ii) a southern sub-unit made of blocks of various lithologies and ages. The presence of blocks was first proposed, but never clearly demonstrated, by Dubreuil (1986). These blocks are scattered in a Middle Devonian pelite-sandstone matrix. This southern sub-unit called "the Olistostrome with exotic block sub-unit" or "the Blocky sub-unit" overthrusts to the North the Sandstone-Pelite sub-unit (Cartier et al., 2001).

\section{Lithostratigraphy, geochemistry and structure of the Blocky sub- unit}

The Blocky sub-unit is limited by the Nort-sur-Erdre fault to the South and bounded to the North by a discontinuous sandstone strip (Figs. 1b, 2). Lenticular shaped blocks with various lithologies and ages were recognized in this area (Fig. 2). The most important are: 1) Silurian black cherts (Llandovery, Philippot, 1950); 2) Late Silurian to Middle Devonian limestones (Lys and Mauvier, 1967; Lardeux, 1967; Vachard, 1993, 1994); 3) mafic lava (Carpenter et al., 1982); 4) acidic lava (Carpenter et al., 1982); 5) sandstone of unknown age. Mafic lavas yield a $\mathrm{Rb} / \mathrm{Sr}$ whole rock Late Silurian age of $400 \pm 24 \mathrm{Ma}$ for the Ingrandes metabasites and acidic lavas yield a $\mathrm{Rb} / \mathrm{Sr}$ whole rock Late Devonian age of 350 \pm 13 Ma (Carpenter et al., 1982). Due to the sensitivity of the $\mathrm{Rb} / \mathrm{Sr}$ method to diffusion processes these ages can be questioned. Mafic volcanics are transformed by intense spilitisation which can provide mobilisation of $\mathrm{Rb}$ and $\mathrm{Sr}$. So the obtained age may better correspond to the spilitization event, which occur probably shortly after the eruption event. Acid rocks are petrologically and geochemically similar to the Middle Cambrian rhyolites that crop out in the Cholet volcanicplutonic complex (Thiéblemont et al., 2001). Therefore in the following, a Cambrian age will be preferred. 


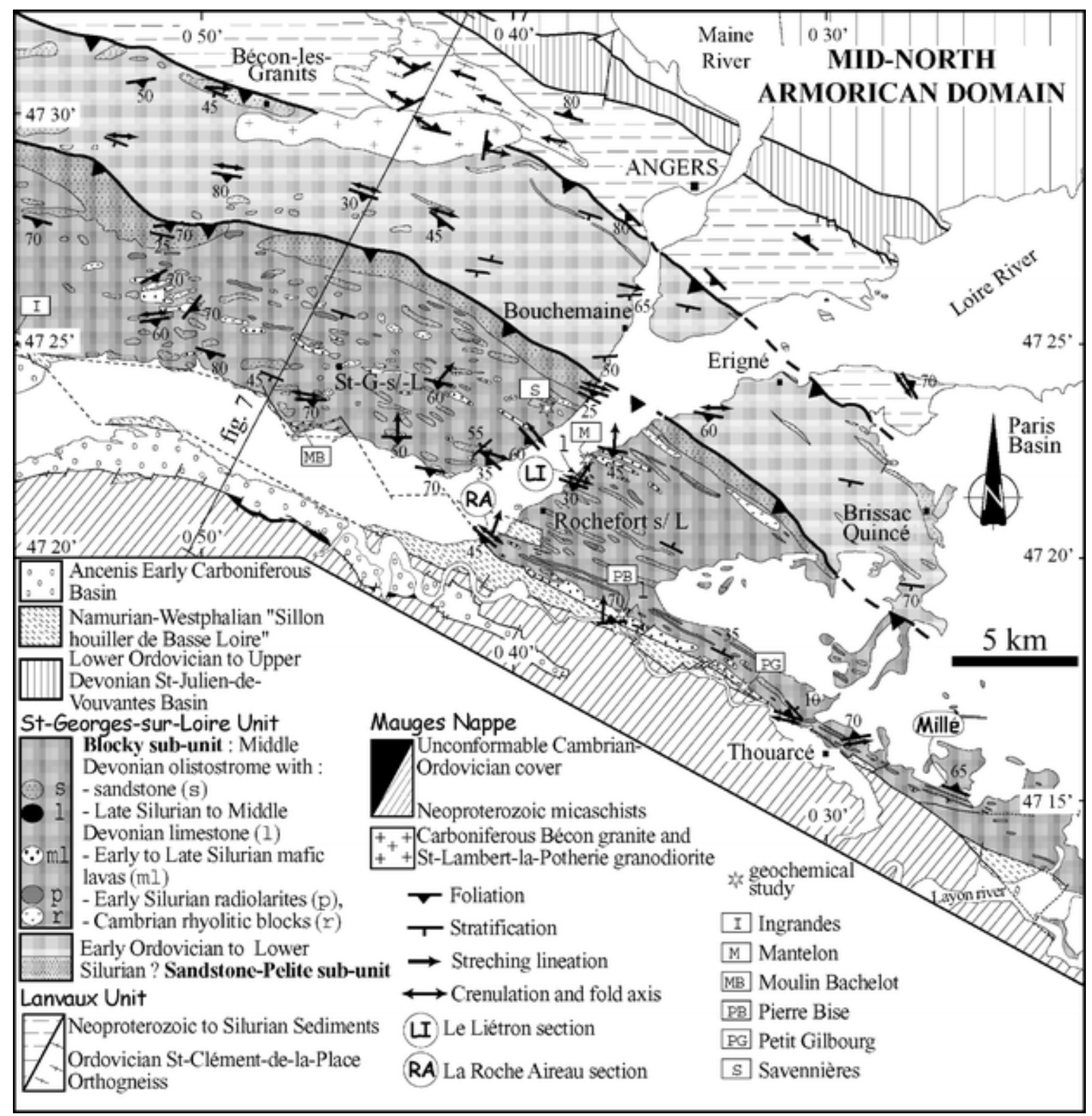

Fig. 2 Detail map of the Eastern part of the Saint-Georges-sur-Loire Unit near Angers

These blocks with various lithologies, ages and sizes are included in a pelite-sandstone matrix. The blocks and matrix relationships can be observed in several key exposures such as the Roche-Aireau section (SW of Angers; Cartier et al., 2001), Millé (S of Angers) and Liétron (SW of Angers) exposures (Fig. 2). These several meters long sections representative of the "Olistostrome with exotic blocks" are described below both for lithological and structural aspects.

\section{Millé section}

In the Millé exposure (Fig. 3A), chert blocks with different shape and size ranging from centimetric clast to metric lens occur in a pebbly-mudstone matrix. Chert beds may appear as continuous at outcrop scale, but are discontinuous and scattered at the regional scale (Fig. 2). From the structural point of view, the Millé section shows a N110E NW dipping cleavage $\left(\mathrm{S}_{1}\right)$ 
which wraps around massive and undeformed chert pebbles or is refracted when it crosses chert lenses. It is then more or less parallel to the bedding surface $S_{0-1}$. The original bedding $\mathrm{S}_{0}$ is also deformed by isoclinal folds with a large scattering of axes from $\mathrm{N} 105^{\circ} \mathrm{E}$ to $\mathrm{N} 5^{\circ} \mathrm{E}$ (Diot and Blaise, 1978). These folds are considered as partly primary synsedimentary structures coeval with block deposition and partly secondary ones due to subsequent regional deformation.
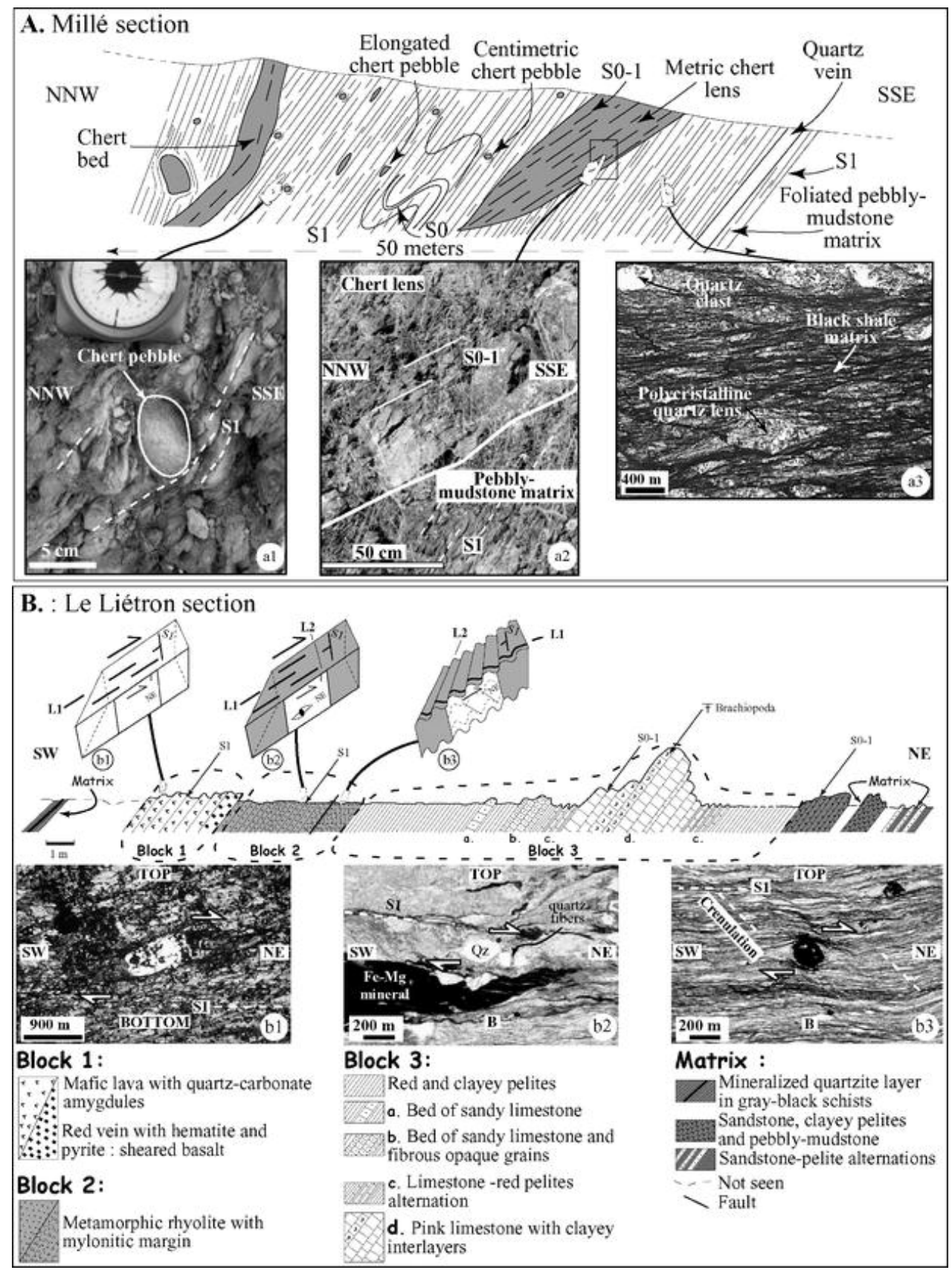

Fig. 3A, B A : Millé section (see Fig. 2 for location), a1: Undeformed centimetric chert pebble. Well marked $\mathrm{S}_{1}$ in the pelitic grey matrix wraps around the pebble, $a 2: \mathrm{S}_{0-1}$ inherited in the metric chert lens is refracted in the pelitic matrix, a3: Thin section of the pebbly-mudstone matrix. B: Le Liétron section (see Fig. 2 for location): lithology, block limits and structure, $b 1$ : Thin section parallel to the mineral stretching lineation $\mathrm{L}_{1}$ and perpendicular to the $S_{1}$ foliation. A quartz-carbonate amygdule with asymmetric tails shows a top to the NE sense of shear in the metabasic lava (block 1), b2: Asymmetric quartz clast with a top to the NE sense of shear in the metamorphic rhyolite (Block 2), b3: opaque mineral with asymmetric chloritic tails giving a top to the NE sense of shear in the mylonitic metarhyolite (Block 2) 


\section{The Liétron section}

In the Liétron section (Fig. 3B), the blocky character may be locally hidden by the subsequent deformation, since the matrix is highly sheared. This section exposes at least three lithologically distinct blocks included into the olistostrome matrix. From SW to NE, block 1 is made of mafic lava, block 2 consists of metarhyolite and block 3 is composed by limestone beds including red pelites. Early Devonian brachiopods, determined by M. Basset and P. Racheboeuf (pers. comm.) have been discovered in the upper part of the limestone mass. The terrigeneous matrix crops out mainly to the NE, in other places it is sheared along the block contacts. It consists of sandstone-pelite alternations and pebbly-mudstone facies composed of a black shale matrix with sandstone and quartz clasts inclusions.

Structurally, this section presents also a conspicuous foliation $\mathrm{S}_{1}$ trending N110E to N140E and dipping $30^{\circ}$ to $50^{\circ} \mathrm{SW}$, well marked in the volcanic rocks of blocks 1 and 2 . In block 3 and in the matrix, this foliation is a $\mathrm{S}_{0-1}$ surface. Matrix and blocks have experienced the same deformation. The $S_{1}$ or $S_{0-1}$ cleavage bears a mineral and stretching lineation $L_{1}$ trending $N 50$ to $\mathrm{N} 60 \mathrm{E}$ and is folded by a $\mathrm{N} 130 \mathrm{E}$ trending very penetrative crenulation lineation $\mathrm{L}_{2} \mathrm{c}$. Thin sections cut parallel to the $\mathrm{L}_{1}$ and perpendicular to the $S_{1}$ or $S_{0-1}$ surfaces allow to determine microscopically the sense of shear. In the mafic lava quartz-carbonate amygdules with asymmetric tails indicate a top-to-the-NE sense of shear. In block 2, the metarhyolite contains sigmoidal quartz clasts showing also a top-to-the-NE sense of shear. In the mylonitic metarhyolite, opaque grains with asymmetric chlorite tails give the same top-to-the-NE sense of shear. In block 3 and in the matrix, due to a stronger crenulation, shear criteria are ambiguous and hardly interpretable.

\section{Other blocks and geochemistry of mafic lava blocks}

Many other blocks are recognized in the Blocky sub-unit as already described (Cartier et al., 2001). Limestone blocks are found only in the eastern part of the Blocky sub-unit (Fig. 2). These limestone blocks exhibit different facies, from monogenetic limestone blocks like the Liétron limestone to polygenetic breccias with limestone, chert and mafic lenses in a quartzcarbonate matrix. Along the Nort-sur-Erdre fault (Fig. 1b), the blocks are strongly deformed, with subvertically elongated limestone lenses in a subvertical $S_{1}$ foliation. It is worth noting that when $S_{1}$ foliation is restored to a flat-lying attitude, this stretching lineation becomes N-S (Fig. 4b). By contrast, some rounded limestone blocks, like those exposed in the Roche Aireau (Fig. 2) are undeformed and the $S_{1}$ foliation wraps around these blocks.

In order to assess their geodynamic setting, some mafic lava blocks have been geochemically analysed by measuring out major and trace elements. Major, minor and trace elements have been measured out by Inductively Coupled Plasma spectrometry (ICP) at Orléans University and by ICP and Mass Spectrometry (ICP-MS) at Toulouse University. The tables of analytic data are available directly upon request to the authors. Mafic lava blocks, mainly located in the eastern part of the Blocky sub-unit (Fig. 2), present various lithologies such as subalkaline to alkaline basalts, andesite and trachyte. These rocks experienced greenschist metamorphism conditions and intense spilitization (e.g. Lardeux and Cavet, 1994). Four samples of these basic lava blocks have been analysed (see location in Fig. 2): i) a doleritic microgabbro (Petit Gilbourg, NW of Thouarcé), ii) a dolerite (Pierre Bise open pit, NW of Beaulieu-sur-Layon), iii) a protoclastic microgabbro with pyroxenes (Mantelon, near Denée, SW of Erigné), iv) a porphyritic basalt with pyroxenes (Savennières, SW of Bouchemaine). 


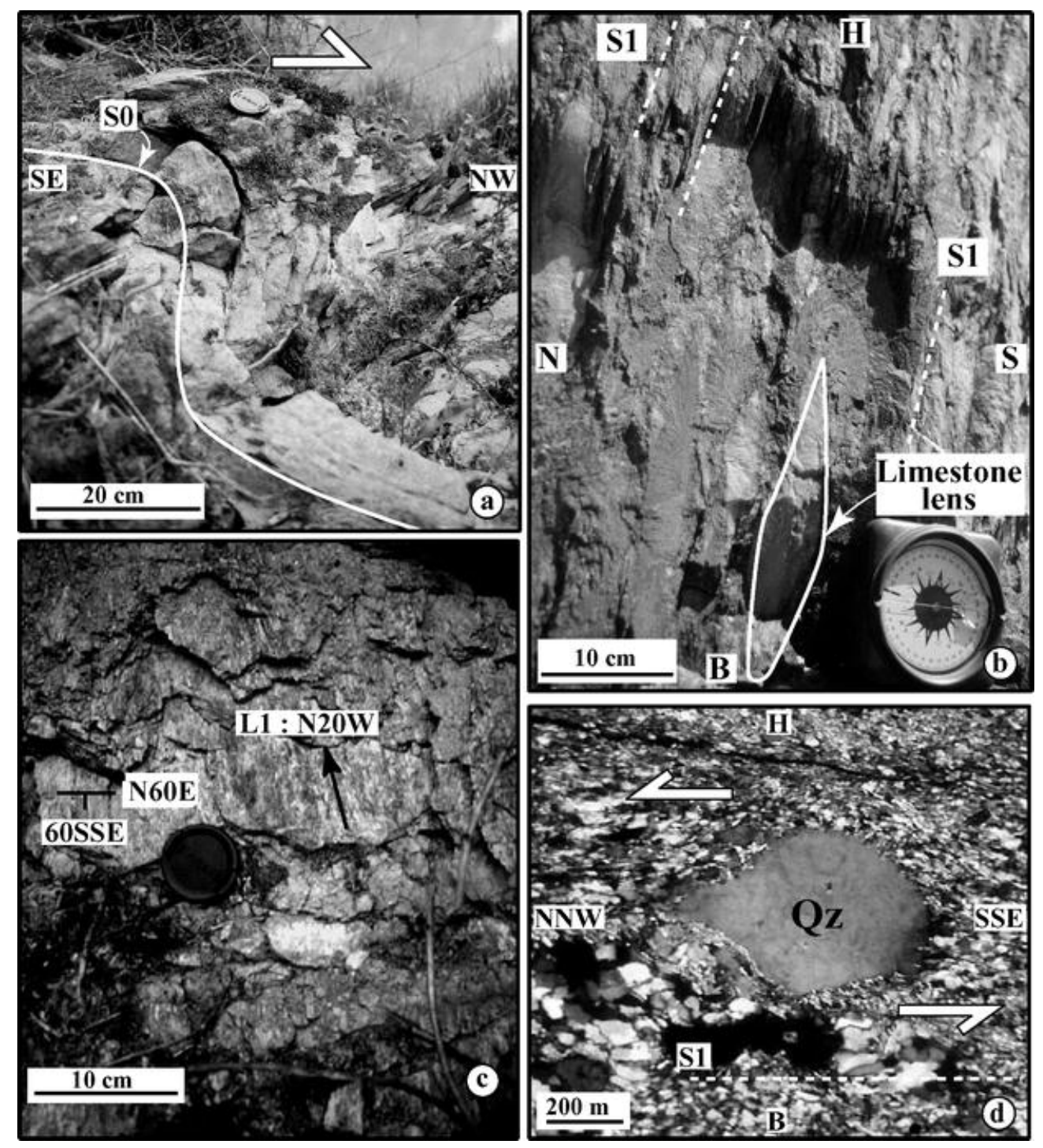

Fig. 4a-d Lithology and kinematics observations in the Saint-Georges-sur-Loire Blocky sub-unit (matrix and blocks). a: Sandstone layers folded by a N80-50SW fold overturned to the NW (Champtocé-sur-Loire, along the left border of the Romme river), b: Polygenic carbonate breccia with limestone lenses elongated in the foliation ( $\mathrm{S}_{1}$ : N140-70NE, Pont-Barré open pit along the Layon river (Beaulieu-sur-Layon)), c: Stretching lineation $\mathrm{L}_{1}$ (N20 W) of quartz and Feldspar clasts in a pelitic matrix (La Chatellière, NE of Nort-sur-Erdre), d: Sigmoidal quartz clast showing a top-to-the-NNW sense of shear in sandy pelite of picture c (thin section parallel to $\mathrm{L}_{1}$ ).

The obtained spider diagrams are compared with the available analyses (Carpenter et al., 1982; Cabanis, 1986). On these spider-diagrams, Ta is not taken into consideration because of an analytical problem while getting ICP-MS data at Toulouse University. The chondritenormalised spider diagram (Fig. 5a) exhibits little enriched spectra in general. Doleritic microgabbro, dolerite, protoclastic microgabbro show similar profiles and are little fractionated with a fractionating degree $\mathrm{La}_{\mathrm{N}} / \mathrm{Yb}_{\mathrm{N}}$ between 1,49 and 1,91. These rocks have a tholeiitic chemistry which is similar to that of the Moulin Bachelot pyroclastics (Cabanis, 1986). The more fractionated $\left(\mathrm{La}_{N} / \mathrm{Yb}_{N}=4,5\right)$ porphyritic basalt is intermediate between $\mathrm{N}$ and E MORB. It comes probably from the melting of a non-depleted mantle as the more 
differentiated rocks of the Ingrandes suite (Cabanis, 1986). The Primordial mantle-normalised spider diagram (Fig. 5b) shows spectra fairly enriched in comparison with the primordial mantle with important variations of $\mathrm{Rb}, \mathrm{Ba}$, and Th because of their mobility during spilitization and metamorphism. The N MORB Normalised spider diagram (Fig. 5c) indicates an enrichment in lithophile elements in comparison with HFS elements. The slightly enriched compared to N MORB porphyritic basalt corresponds to an island arc tholeiite. Others spectra are little enriched or depleted with a possible N MORB source. In the Th/Ta/Tb diagram, our data plot in the anorogenic E MORB field for the porphyritic basalt and in the fore-arc and immature back-arc basin in an orogenic or anorogenic context for others samples (Fig. 5d).

In spite of still rare geochemical constraints, our own analyses comply with those already performed Cabanis (1986). They show that the mafic rocks of the Saint-Georges-sur-Loire Blocky sub-unit belong to two main geodynamic settings. Some of the lava probably formed at a spreading centre and some belongs to an active continental margin such as magmatic arc and back-arc basin. These conclusions will be used for the establishment of the geodynamic model presented in the section titled "Discussion of a geodynamic evolution model $"$. 


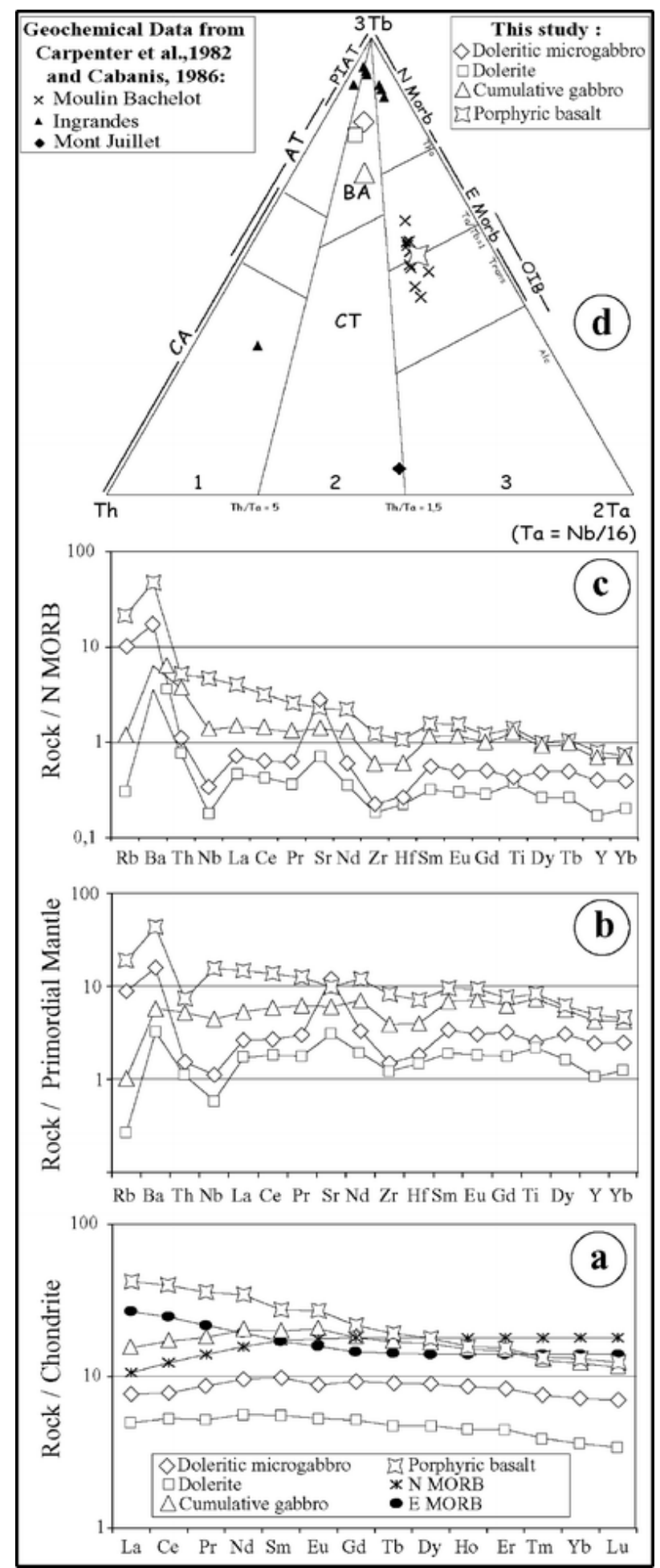

Fig. 5a-d Geochemical data on mafic blocks of the Saint-Georges-sur-Loire Blocky sub-unit, normalisation after Sun and McDonough, 1989. a: Chondrite-normalised REE element patterns for basaltic rocks from the Saint-Georges-sur-Loire Blocky Unit. b: Primordial mantle-normalised element patterns. c: N MORBnormalised element patterns. d: Th-3Tb-2Ta diagram (Cabanis and Thiéblemont, 1988). This diagram has been drawn with $\mathrm{Nb} / 16$ instead of $\mathrm{Ta}$ because $\mathrm{Ta} / \mathrm{Nb}$ is a constant value in volcanic suite with a mantle origin (Bougault et al., 1980). 1: orogenic series (CA: calc-alkaline basalts; AT: Arc tholeiites; PIAT: Primitive Island Arc tholeites); 2:" intermediate" series (BA: fore-arc and immature back-arc basin basalts; CT: Continental Tholeiites); 3: anorogenic series (Tho: N-MORB and more rarely E-MORB ; Trans: Transitional basalts; Alc: ocean island (OIB) and continental alkali basalts). 


\section{The matrix}

The terrigeneous part of the Blocky sub-unit has been interpreted as a flysch deposit (Lardeux and Cavet, 1994). Lithologically, it consists of pelitic rocks (argillite, siltite), but massive sandstone are also found. Moreover, the most significant rock-type is the pebbly mudstone facies. All these facies argue for an unstable sedimentation setting, controlled by gravity sliding and active tectonics. The matrix age is unknown, but it must be younger than the youngest block, i.e. younger than Middle Devonian. Recently, and for the first time, some small spores associated with organic fragments and vegetal tissues have been extracted from a pelite sampled around a sandstone block near Rochefort-sur-Loire, SW of Angers (Fig. 2). This pelite was first considered as a matrix sample, but a preliminary examination of the spore association by P. Steemans (Liège University, Belgium) suggests a Ludlow to Praguian age. This Late Silurian to Early Devonian age is older than the expected one for the matrix. The question to know if the sample picked around the sandstone block is really representative of the matrix arises. New samples have been collected at the same place and some of them contain centimetric pebbles within the matrix. Thus the age obtained by P. Steemans might rather correspond to that of an olistolith. Presently, new microfossil extractions are in progress to settle the age of the matrix.

The bedding surface, $\mathrm{S}_{0}$, clearly observed in the matrix by the pelite-sandstone alternation is folded by $\mathrm{P}_{1}$ north verging folds with N80 to N120 axes (Fig. 4a.). An axial planar cleavage $\left(S_{1}\right)$ develops in the fold hinge. Along the fold flanks, $S_{1}$ is parallel to $S_{0}$, this $S_{0-1}$ surface is often a slip surface. Near the Nort-sur-Erdre fault, a penetrative mineral stretching lineation $\mathrm{L}_{1} \mathrm{~N} 20 \mathrm{~W}$ nearly perpendicular to the fault trend has been found on the $\mathrm{S}_{1}$ foliation (Fig. $4 \mathrm{c}$ ). In thin section parallel to $L_{1}$ and perpendicular to $S_{1}$, sigmoidal quartz grains indicate a-topto-the-NNW sense of shear (Fig. 4d).

\section{The Sandstone-Pelite sub-unit}

The Sandstone-Pelite sub-unit crops out North of the Blocky sub-unit and overthrusts to the North the Cambrian-Ordovician sedimentary rocks of the Lanvaux Unit (Figs. 1b, 2). From top to bottom, this sub-unit is made of a monotonous alternation of schist and sandstone to the South and a massif sandstone-quartzite layer with rare slaty black schists on its northern border, called "sandstone of the Ancenis forest" or "Abbaretz-Bécon rise" (Cavet et al., 1986). This sedimentary series was considered as Middle Ordovician to Lower Silurian (Cartier et al., 2001). Recently, Early Ordovician chitinozoa (i.e. Arenig, determined by F. Paris, Rennes University), have been extracted from the black schist layers of the sandstonequartzite strip.

In the Sandstone-Pelite sub-unit, the bedding $S_{0}$ is folded by upright or North verging folds with an axial planar $S_{1}$ cleavage (Fig. 6a). A N90 to N140 stretching and mineral lineation $\mathrm{L}_{2}$ is better expressed when moving northward to the Lanvaux Unit. In a section parallel to $\mathrm{L}_{2}$, asymmetric quartz indicate a top-to-the-NW or SE shearing (Fig. 6b). The stretching lineation $\mathrm{L}_{2}$ is well expressed by quartz elongation in the sandstone-quartzite strip which exhibits several structural facies, namely: i) a poorly oriented sandstone with still well preserved bedding, ii) lineated quartzites with an heterogranular texture showing millimetric clasts in a recrystallized quartz matrix (Fig. 6c), iii) mylonites with polycrystalline quartz ribbons presenting an isogranular texture (Fig. 6d). In sections parallel to $\mathrm{L}_{2}$, several shear criteria such as asymmetric quartz phenocrysts and oblique subgrain boundaries indicate top-to-theEast movement (Fig. 6c). However, opposite sense of shear can be observed in the mylonitic facies (Fig. 6d). 

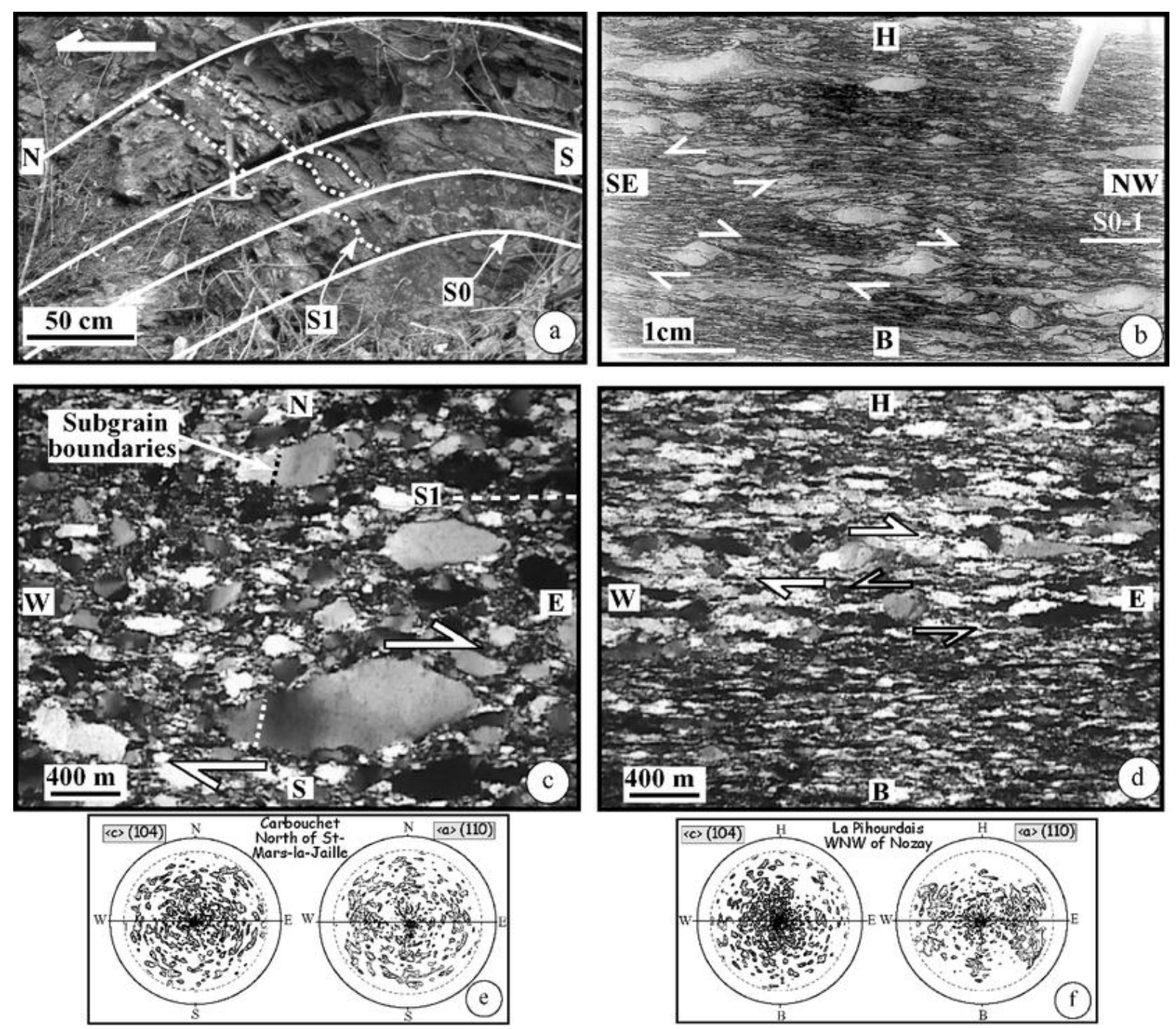

Fig. 6a-f Lithology and kinematics of the Saint-Georges-sur-Loire Sandstone-Pelite sub-unit. a: folded sandstone shale alternation. The N100 E trending fold is overturned to the North (La Cour Romagne, NE of Villemoisan). b: Thin section parallel to the $\mathrm{L}_{2}$ stretching and mineral lineation (N130) and perpendicular to the $\mathrm{S}_{1}$ foliation showing asymmetric quartz sheared to the SE or to the NW (close to the thrust contact with the Lanvaux Unit, near Pruniers, lac de Maine, SW of Angers). c: Thin section parallel to $\mathrm{L}_{2}$, and perpendicular to the $S_{1}$ foliation in sandstone. This rock consists of millimetre-scale quartz clasts in a fine grained quartzose matrix. Quartz clasts frequently exhibit oblique subgrain boundaries (Carbouchet open pit, N of Saint-Mars-laJaille). d: Thin section parallel to $L_{2}$ and perpendicular to $S_{1}$ in a mylonitic quartzite showing two senses of shear, namely top to the West and top-to-the East (La Pihourdais, NW of Nozay). e: Quartz $<$ c $>$ and $<$ a $>$ axis diagrams for quartzite of picture c (Schmidt net, lower hemisphere). f: Quartz $<\mathrm{c}>$ and $<\mathrm{a}>$ axis diagrams for mylonitic quartzite of picture $\mathbf{d}$ (Schmidt net, lower hemisphere).

Quartz $<\mathrm{c}>$ and $<\mathrm{a}>$ lattice preferred orientation measurements have been also done on the same samples by an automatic $\mathrm{X}$ ray texture goniometer in Orléans University. The obtained pole diagrams are presented as an equiareal projection in the XZ plane (Fig. 6e, f). In the quartzite sample with quartz phenocrysts, quartz $<c>$ axis pole figure is symmetrical and diffuse (Fig. 6e). Quartz $<$ a $>$ axis diagram shows a weakly oriented fabric, thus no conclusion on the intracrystalline slip systems and related kinematics can be deduced (Fig. 6e). In the mylonitic sample, quartz $<\mathrm{c}>$ axis pole figure exhibits a maximum around the finite strain intermediate $\mathrm{Y}$ axis, suggesting that the prismatic $<\mathrm{a}>$ slip system has been active in medium 
temperature conditions $\left(450-350^{\circ} \mathrm{C}\right.$, Fig. 6f). Quartz $<\mathrm{a}>$ axis preferred orientation presents three symmetrical maxima with respect to the XY plane (Fig. 6f). Therefore the quartz preferred orientation might suggest that the sandstone-quartzite strip experienced a coaxial flow regime. However, as shown by the microscopic observation, this symmetric pattern results of the combination of two opposite senses of shear. This kinematic pattern can be explained in the general framework of the Ligerian domain.

\section{The Bulk Structure of the Saint-Georges-sur-Loire Unit}

The bulk structure of the Saint-Georges-sur-Loire Unit is a north verging wedge, cut to the South by the Nort-sur-Erdre fault (Fig. 7). The same deformation is observed both in Blocky and Sandstone-Pelite sub-units. Two major tectonic events are responsible for the general architecture, however an early deformation coeval with the development of syn-sedimentary structures may also develop during block formation. Moreover, the Late Carboniferous dextral wrenching plays an important role in the final stage of the orogeny, but this phenomena is beyond the scope of this paper. There is no direct field evidence of the northward thrusting between the two sub-units of the Saint-Georges-sur-Loire Unit along the northern sandstone strip of the Blocky sub-unit (Ledru et al., 1986). However, this contact is likely, as inferred from the contrasted lithologies exposed on each sub-unit. North-directed movements are deduced from the vergence of $\mathrm{P}_{1}$ folds observed in the Blocky sub-unit. In agreement with Cavet et al. (1986) and Lardeux and Cavet (1994), the tectonic contact of the Early Ordovician to Early Silurian Sandstone-Pelite sub-unit overthrust upon the terrigeneous Cambrian-Ordovician rocks of the Lanvaux Unit is located in the Silurian black shales (called Houx ampelites) which phyllitic mineralogy enhances the development of a shear zone.

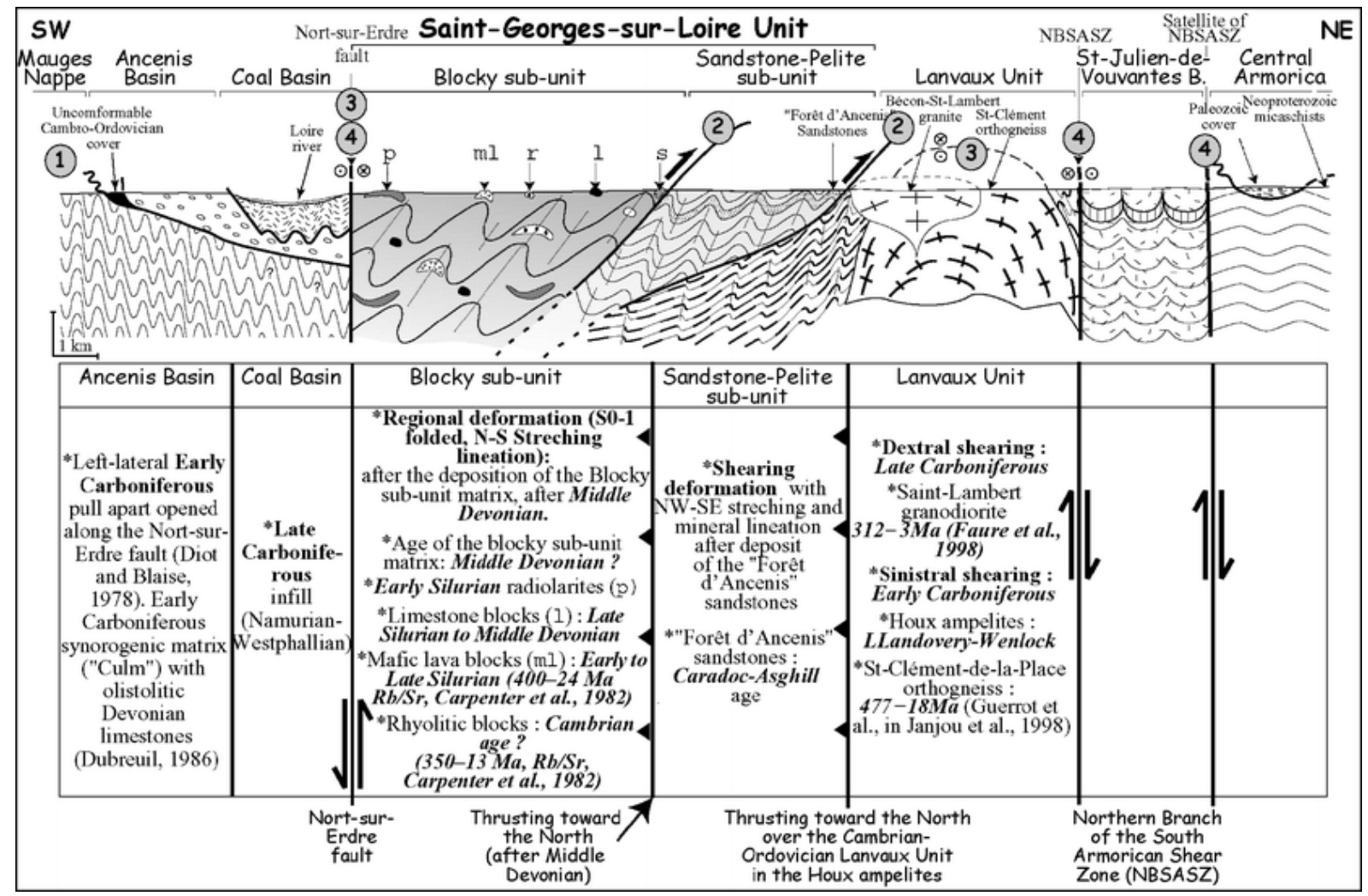

Fig. 7 General cross section of the Ligerian domain showing the structure of the Saint-Georges-sur-Loire Unit and surrounding. Circled numbers correspond respectively to the first, second, third and fourth deformation stage. 
In summary, the structural development of the Saint-Georges-sur-Loire Unit results of two successive deformation phases. The first deformation (D1) consists of the folding of the $\mathrm{S}_{0}$ bedding by N100 to N140E trending folds overturned to the North in both sub-units. The south dipping $S_{1}$ axial planar cleavage of the $P_{1}$ folds becomes parallel to $S_{0}$ in the fold limbs $\left(\mathrm{S}_{0-1}\right)$. This $\mathrm{S}_{1}$ cleavage bears a N-S to $\mathrm{N} 50 \mathrm{E}$ trending stretching $\mathrm{L}_{1}$ lineation. Top-to-the North shearing is widespread both in hand samples and thin sections. The second deformation (D2) is marked by the micro-folding of $\mathrm{S}_{0}$ or $\mathrm{S}_{0-1}$ surfaces by $\mathrm{N} 110 \mathrm{E}$ trending $\mathrm{P}_{2}$ folds. The crenulation lineation $\mathrm{Lc}_{2}$ is parallel to an intersection lineation $\mathrm{Li}-\mathrm{C}_{2}$ parallel to fold axes. These $\mathrm{LC}_{2}$ and $\mathrm{Li}-\mathrm{C}_{2}$ lineations are well observed in the pelitic rocks of both sub-units. When moving northwards to the Lanvaux Unit, the $\mathrm{S}_{0-1}$ surface flattens and the NW-SE crenulation $\mathrm{LC}_{2}$ is superimposed by a conspicuous E-W to NW-SE stretching and mineral lineation $\mathrm{L}_{2}$. This $\mathrm{L}_{2}$ lineation is poorly expressed in the Blocky sub-unit, where it can be observed mainly in the competent blocks. Conversely, $\mathrm{L}_{2}$ is well developed in the sandstone and quartzite facies of the Sandstone-Pelite sub-unit. In thin sections cut parallel to the $\mathrm{L}_{2}$ lineation, asymmetric markers indicate a top to the NW or to the SE sense of shear.

\section{Discussion of a geodynamic evolution model}

\section{The Lanvaux Unit and Ancenis basin}

As presented above, the Saint-Georges-sur-Loire Unit is only a part of the Ligerian domain. In order to better understand the evolution of the northern Ligerian domain it is necessary to present the structure of the Lanvaux Unit and the Ancenis basin (Fig. 1b). North of the SaintGeorges-sur-Loire Unit, the Lanvaux Unit is composed of an Early Ordovician orthogneiss, called in the study area the Saint-Clément-de-la-Place orthogneiss, (Vidal 1980; Guerrot et al. in Janjou et al., 1998) and a metasedimentary cover of pelite and sandstone ranging from Neoproterozoic to Late Ordovician in age (Figs. 1b, 2; Lardeux and Cavet, 1994). Both parts are intruded by Late Caboniferous granites. In the Saint-Clément-de-la-Place orthogneiss, the foliation definies an anticline and bears a well preserved NW-SE trending mineral stretching lineation (Bouchez and Blaise, 1976). A polyphase deformation implying two senses of shear with the same direction has been recognized (Faure and Cartier, 1998). An early sinistral shearing responsible for the top-to-the-NW motion on subhorizontal mylonitic foliation is reworked by a second dextral wrenching developed on a vertical foliation. This late deformation is coeval with the emplacement of the Late Carboniferous granitoids.

The Ancenis basin crops out south of the Saint-Georges-sur-Loire Unit, along the Nort-surErdre fault and within the Mauges Nappe (Fig. 1b). It is composed of an Early Frasnian formation and a turbiditic Frasnian-Dinantian "culm" series (Dubreuil, 1986; Lardeux and Cavet, 1994). In agreement with Blaise et al. (1970) and Diot and Blaise (1978), we interpret this basin as opened as a sinistral pull-apart along the Nort-sur-Erdre fault, within the Mauges Nappe. The sinistral shearing related to basin opening is recorded in the Neoproterozoic basement and its Early Frasnian cover by brittle faults and in the drag folds and in the Dinantian turbidite by slumps and synsedimentary structures. Our own field survey does not support the interpretation of the Ancenis basin as a dextral pull-apart, detached and translated like an "exotic duplex" along a transcurrent NE-SW fault proposed by Shelley and Bossière (2001) and discussed by Cartier et al. ( 2002a).

\section{The structural evolution of the Ligerian domain}

At least four deformation stages with different displacement directions, metamorphic conditions and ages developed on both sides of the Nort-sur-Erdre fault are responsible for the final structure of the Ligerian domain (Figs. 1b, 7). The first stage, observed south of the Nort-sur-Erdre fault, corresponds to the synmetamorphic ductile thrusting that leads to the 
stacking of the Champtoceaux nappes complex and the overlying Mauges basement nappe upon the para-autochtonous Mauves Unit (Marchand, 1981).

The second stage, recognized north of the Nort-sur-Erdre fault in the Saint-Georges-sur-Loire and Lanvaux Units, is responsible for the above described D1 deformation. This event is a top-to-the-North thrusting that takes place after Middle Devonian which is the matrix age of Blocky sub-unit and before the Early Carboniferous opening of the Ancenis basin. It is worth noting that this deformation has not been recognized south of the Nort-sur-Erdre fault.

The third stage is represented by the top-to-the-NW D2 shearing in the Saint-Georges-surLoire Unit, in the Lanvaux Unit and the left-lateral wrenching along the Nort-sur-Erdre fault which controls the pull apart shape of the Ancenis basin. The age of this deformation is dated as Early Carboniferous by the syntectonic sedimentary infill of culm deposits in the Ancenis basin.

Lastly, the fourth deformation stage is marked by a Middle to Late Carboniferous (Namurian to Westphalian) dextral shearing along the Northern Branch of the South Armorican Shear Zone. Numerous peraluminous Carboniferous leucogranites characterized by S-C structures were emplaced during this event.

The structural scenario presented above allows us to draw the general cross section of the Ligerian domain (Fig. 7). This section complies with the seismic profile trough Southern Brittany presented in Bitri et al. (2003).

\section{The Ligerian domain in a Paleozoic geodynamic reconstruction}

The paleogeography of Gondwana is still controversial, different Paleozoic reconstructions are proposed according to paleomagnetism, tectonics, and paleontology (e.g. Paris, 1998; Tait et al. 2000; Cocks, 2000; Matte, 2001; Robardet, 2003 and enclosed references). The above described lithological, stratigraphic, geochemical and structural features of the Saint-Georgessur-Loire Unit and surrounding areas allow us to develop a geodynamic scenario for the Ligerian domain during Paleozoic times replaced in a general paleogeographic reconstruction. This model (Figs. 8, 9, 10) presents three different stages of a continuous evolution which implies two diachronic subductions. 
Middle Ordovician (465Ma)

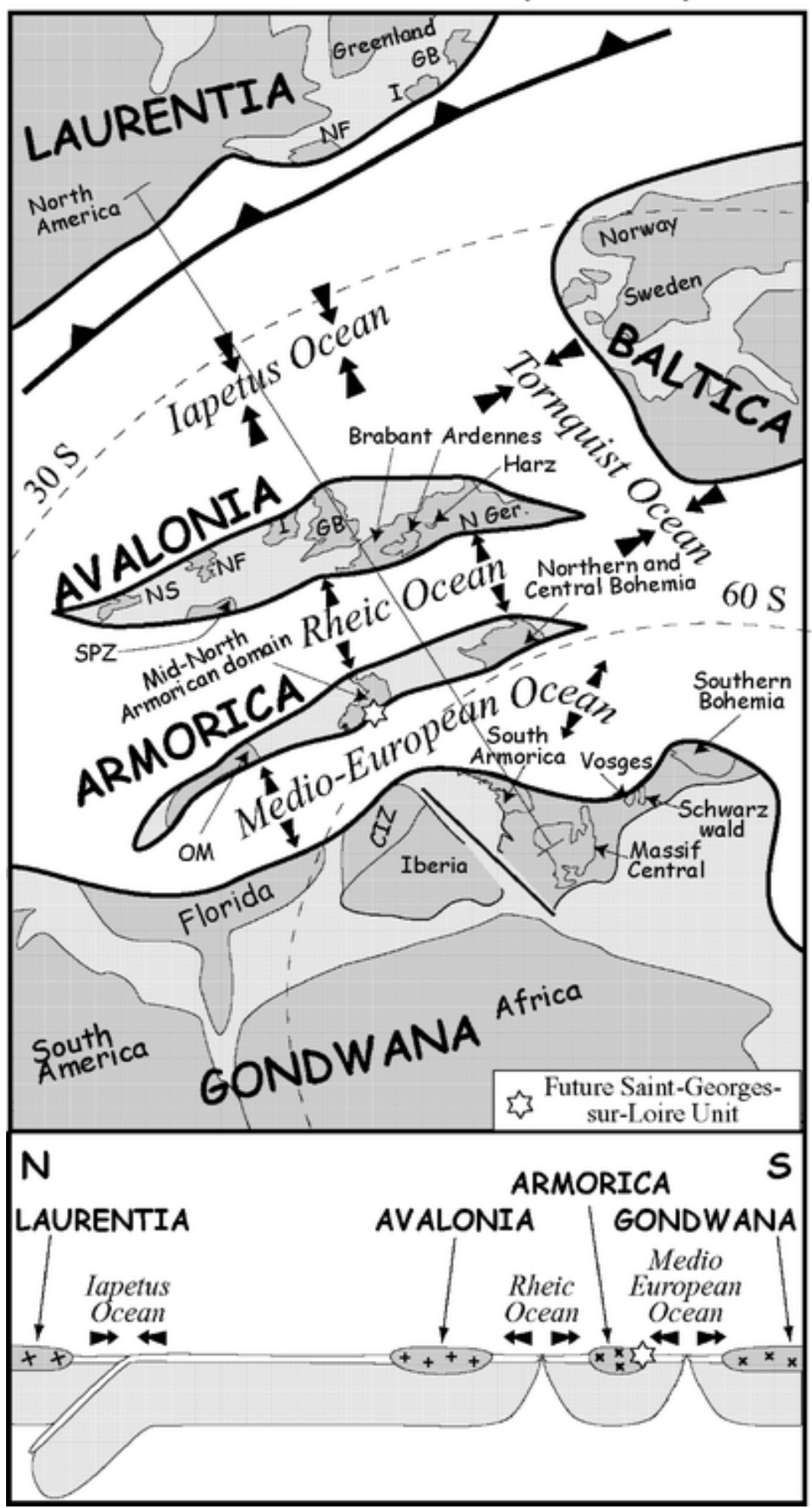

Fig. 8 Geodynamic reconstructions in map and cross section of the Ligerian domain in the general paleogeographic frame of Western Europe. Maps are redrawn from Matte (2001). Middle Ordovician (Open star: Future Saint-Georges-sur-Loire Unit; NF: Newfoundland, I: Ireland, GB: Great Britain, OM: Ossa Morena, SPZ: South Portuguese Zones, and CIZ: Central Iberian Zone 


\section{Middle to Late Silurian (425-410Ma)}

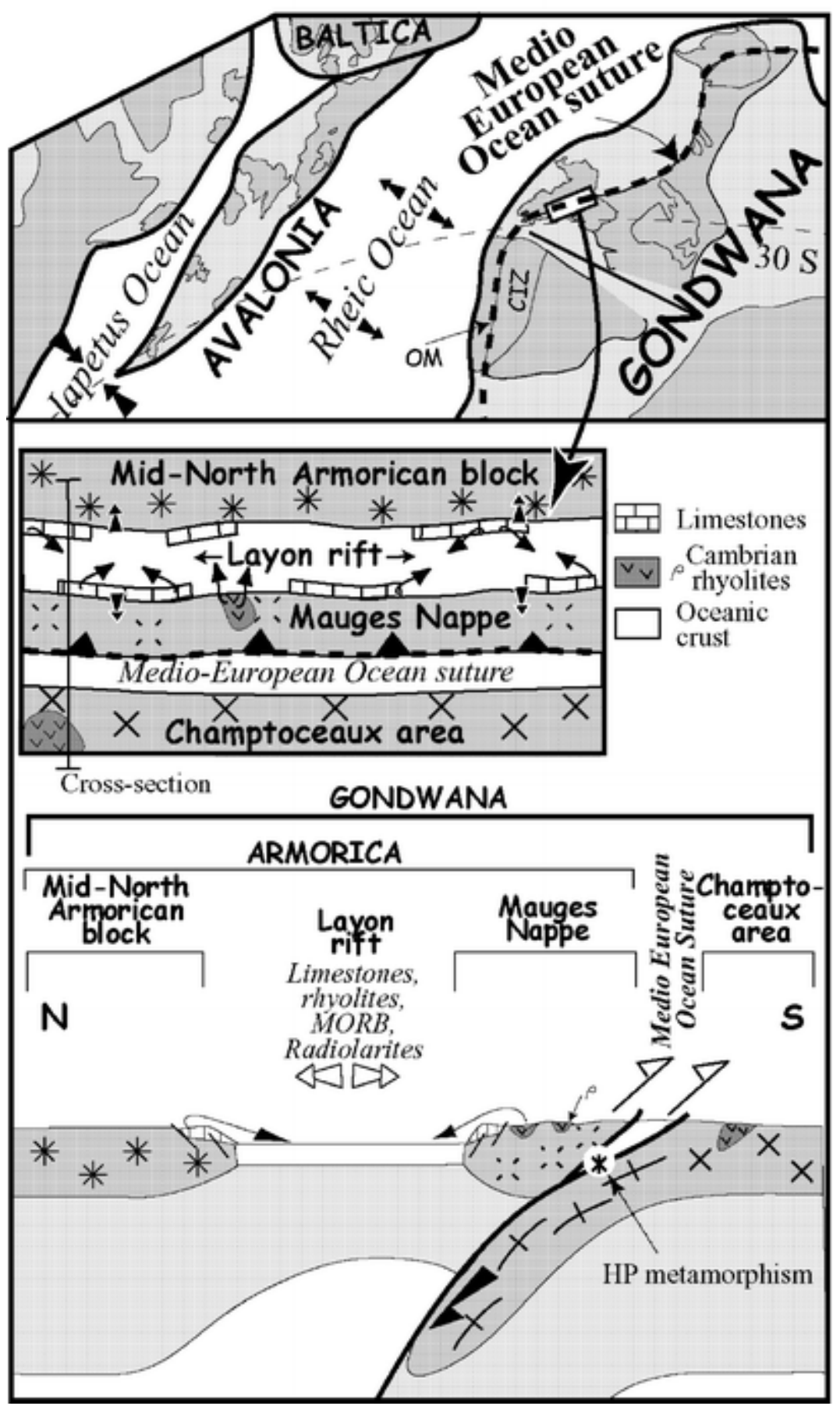

Fig. 9 Geodynamic reconstructions in map and cross section of the Ligerian domain in the general paleogeographic frame of Western Europe. Maps are redrawn from Matte (2001). Middle to Late Silurian 


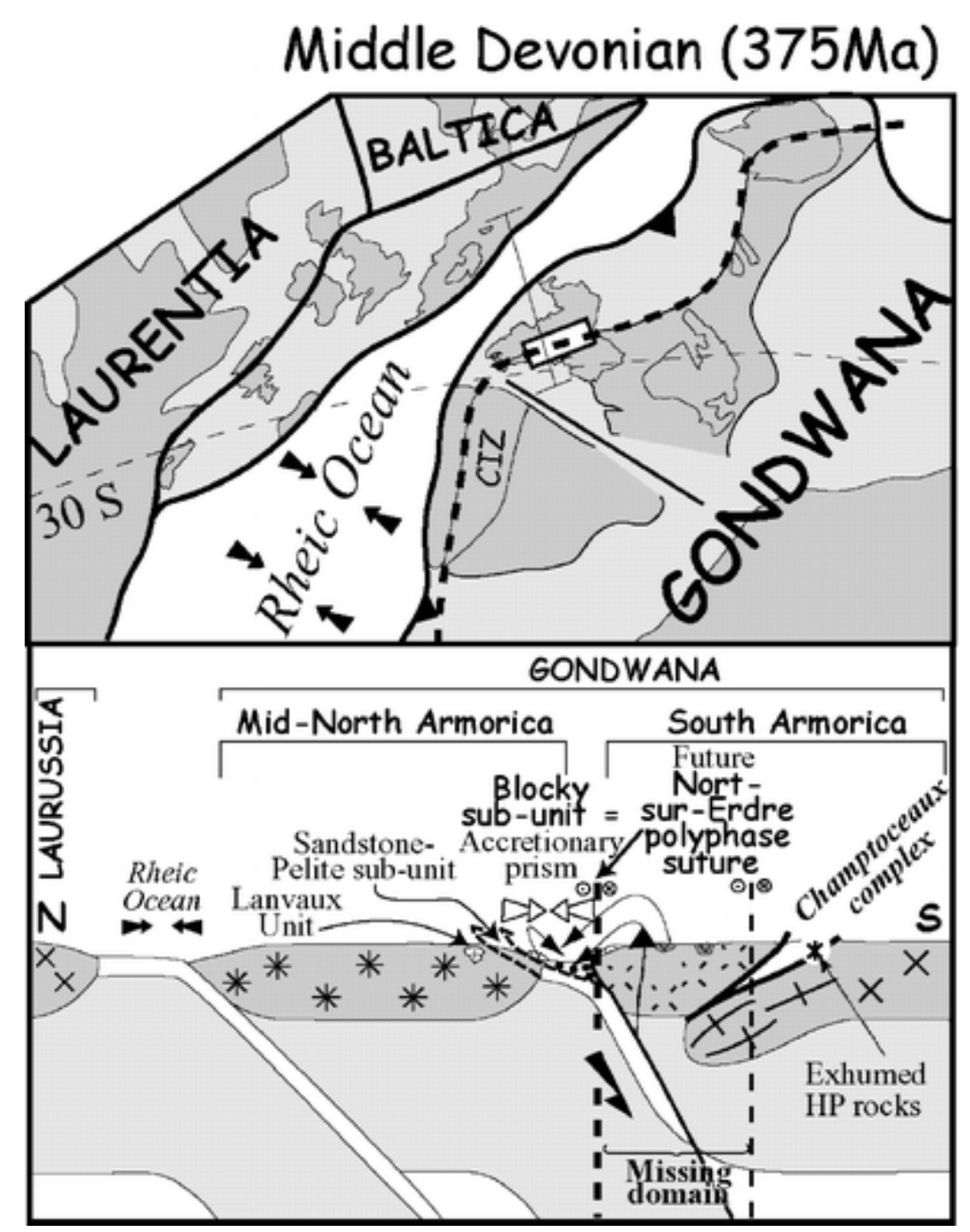

Fig. 10 Geodynamic reconstructions in map and cross section of the Ligerian domain in the general paleogeographic frame of Western Europe. Maps are redrawn from Matte (2001). Middle Devonian

On the basis of faunistic and paleomagnetic arguments, there is a general agreement to recognize in Middle Ordovician time, around $465 \mathrm{Ma}$, three major continents, namely: Laurentia, Baltica and Gondwana to the North, East and South (Fig. 8). Two continental strips derived from the North Gondwana margin: Avalonia and Armorica to the North and South respectively can also be distinguished. Avalonia includes the Rheno-hercynian zone of Northern Europe (with Northern Germany, Ardennes, southern Britain, southern Ireland) South Portuguese Zone, Eastern Newfoundland, Nova Scotia, New Brunswick and Eastern New England. This Avalonia microcontinent drifted from Gondwana in Late Ordovician times. Conversely, the Armorica microplate is not widely acknowledged due to faunal similarities and non reliable paleomagnetic data. However, the occurrence of Late Silurian eclogites with an oceanic signature in the south part of the Armorican massif (e. g. Champtoceaux Complex, Vendée, Groix island) and in several places of the Massif Central suggests that an oceanic area was involved in subduction-collision processes (Pin, 1990; Matte, 1986; Ballèvre et al., 1987; Faure et al., 1997). Therefore, in agreement with Matte (2001), our preferred geodynamic reconstruction for the Middle Ordovician considers the Avalonia and Armorica microcontinents separated by an expanding Rheic ocean. The drifting continental strip of Armorica is separated from the main part of Gondwana by an oceanic 
domain variously called: Massif Central, Galicia or South Armorican ocean (Cogné, 1977; Matte 1986, 2001). Since high pressure oceanic rocks develop from Iberia to Bohemia, we prefer to use the name of "Medio-European Ocean" for this area. Since the Medio-European Ocean started to open in Early Ordovician, it is not surprising to found similar Cambrian rocks in the Mid-North Armorican domain which belongs to Armorica and in the Massif Central and south part of Armorican massif which belong to the northern margin of Gondwana. For instance, Cambrian rhyolites with comparable geochemistry occur in Normandy, in Vendée and in south and west Massif Central, that is to say on both sides of the Medio-European Ocean (Thiéblemont and Cabanis, 1994). Moreover, a rough estimate shows that the Medio-European Ocean lasted from Early Ordovician to Late Silurian, about 70 Ma. Thus, assuming the same duration of opening and closing and a mean spreading rate of $20 \mathrm{~km} / \mathrm{My}$, the maximum width of the Medio-European Ocean was around $700 \mathrm{~km}$. Such a small size does not allow significant faunal distinction on both sides of the ocean.

In Middle to Late Silurian, between 425 and $410 \mathrm{Ma}$, Avalonia had drifted to the North, inducing the closure of the Tornquist ocean, and the Iapetus subduction continued (Fig. 9). To the South, the Rheic Ocean continued expanding whereas the Medio-European Ocean was closed by a northward subduction under Armorica. The Early Silurian Medio-European Ocean subduction was followed by a continental subduction which was responsible for the high pressure metamorphism. It is worth noting that high-pressure rocks from the Champtoceaux unit and Groix island yield Sm-Nd and Ar-Ar ages of 360 and 370 Ma which are considered as those of the high-pressure metamorphism (Bosse et al., 2000). As it is discussed in Faure et al. (1997), the date of 360 Ma (Bosse et al., 2000) might not be the real age of the high-pressure metamorphism event. The 360 Ma age could rather correspond to the thermal and tectonic Hercynian events, therefore we propose a resetting of all the chronometers due to this tectonics. However, these ages do not comply with that of the migmatization that overprints the high pressure rocks in the Champtoceaux Complex. Monazite from those migmatites yields a U-Th-Pb chemical age of 386 $\pm 6 \mathrm{Ma}$ (Cocherie et al., 2004; cf. discussion in Cartier et al., 2001).

The Proterozoic basement and Paleozoic cover of the Mauges Nappe argues for a collision between Gondwana and Armorica. However, the sedimentary continuity in the Paleozoic sequence and the lack of any disturbance between Silurian and Devonian deposits of MidNorth Armorican domain suggest that this area did not recorded the collisional event. A close up around the future Ligerian domain (Fig. 9) allows us to explain this phenomenon. The E and N-MORB compositions of the Moulin Bachelot and Ingrandes mafic lavas, and the deposition of Early Silurian radiolarites suggest a distensional setting called the " ${ }^{\text {" }}$ Layon rift ${ }^{3 "}$. Such a rift that separates the Mid-North Armorican domain and the Mauges Nappe from north to south respectively accounts for the lack of a sedimentary, structural or metamorphic disturbance in the Mid-North Armorican domain. The onset of crustal thinning and width of the Layon rift remain unknown, but in spite of the lack of typical ophiolites, Early and Middle Silurian siliceous deposits and vesiculated pillow lavas suggest a deep sea setting. Since rifting lasted for nearly 70 to $80 \mathrm{My}$, thus a minimum width of two or three hundred kilometres can be inferred and consequently a possible limited oceanization cannot be ruled out. A modern day analogue of such a geodynamic setting can be found in the Aegean or Tyrhenian seas in Mediterranean Sea. Similar to the Massif Central, the Champtoceaux high pressure rocks experienced syn to post-exhumation migmatization in Early Devonian around 385 Ma (Faure et al., 1997; Cartier et al., 2002b). 
In Middle Devonian (around $375 \mathrm{Ma}$ ), the Rheic ocean is closing by subduction below Gondwana (Fig. 10). The final closure of this ocean in this part of the Variscan Belt occurred around $360 \mathrm{Ma}$, in Late Devonian-Early Carboniferous (Faure et al., 1997). In Middle Devonian, the Layon rift started to close by subduction under the Mauges Block. In the Blocky sub-unit, olistoliths were included by gravity sliding into the Middle to Late Devonian sandy and pelitic matrix. The source of the blocks can be easily explained in this geodynamic scenario. The acidic lava blocks come from the Cambrian volcano-sedimentary cover of the Mauges Nappe. Silurian cherts and mafic volcanics with tholeiitic signature belong to the Layon rift. Calck-alcaline volcanic rocks are derived from an island arc, and Silurian or Early to Middle Devonian limestones belong to the sedimentary cover of the arc or to the rift margin. As a whole, the Blocky sub-unit can be interpreted as an accretionary prism related to the closure of the Layon rift. The D1 deformation of Saint-Georges-sur-Loire Blocky sub-unit is consistent with a southward subduction. The complete closure of the Layon rift, with thrusting of the Blocky sub-unit upon the Sandstone-Pelite sub-unit and this latter upon the Lanvaux Unit, occurred in Late Devonian as shown by the Fammenian unconformity found in the Saint-Julien-de-Vouvantes Unit (Lardeux, 1969). The D2 event described in the Sandstone-Pelite sub-unit of the Saint-Georges-sur-Loire Unit and in the Lanvaux Unit characterized by top-to-the-NW or left lateral shearing on flat-lying or vertical foliation respectively, corresponds to a late increment of the same tectonic event. The D1 and D2 deformations are both kinematically consistent with a bulk N-S convergence. The subvertical bedding and cleavage in the vicinity of the contact between the Mauges Nappe and SaintGeorges-sur-Loire Blocky sub-unit developed during the sinistral Early Carboniferous strikeslip faulting coeval with the opening of the Ancenis basin in Early Carboniferous is also consistent with D2 event. Presently, the Nort-sur-Erdre fault is the boundary between the Saint-Georges-sur-Loire Unit and the Mauges Nappe, but it corresponds as well to the suture zone of the Medio-European Ocean and to the south boundary of the Saint-Georges-sur-Loire Unit. The close proximity of these two major but diachronous geodynamic elements suggests that a part of the Neoproterozoic Mauges Nappe disappeared. Such a "missing domain " as suggested by Dubreuil (1986) might be the consequence of wrench tectonics.

\section{Conclusion}

Due to its special place in the Ligerian domain, the Saint-Georges-sur-Loire Unit appears as an intermediate area between Mid-North Armorican domain and South Armorica/Massif Central during Middle Paleozoic times and subsequently a buffer structural zone between the Armorica microplate and Gondwana. This fact implies a re-examination of the evolution of the West European Variscan belt in Paleozoic times. The peculiarity of the Saint-Georges-surLoire Unit is due to the existence of its southern Blocky sub-unit, considered as a Devonian chaotic formation, built by the closure of the Layon rift and later sheared to the North. Owing to the late Carboniferous deformation, the trace of the Layon suture zone is combined with the Medio-European suture zone in the Nort-sur-Erdre fault which becomes a major polyphase suture zone. This model is consistent with the polyorogenic geodynamic evolution of the Variscan Belt.

\section{Acknowledgements}

H. Lardeux guided us to key outcrops, F. Paris and O. Monod provided many valuable scientific advices to improve our work both in field and lab analyses. M. Polvé is thanked for allowing us the use of ICP-MS for the geochemistry of mafic rocks. 


\section{References}

Ballèvre M, Kiénast JR and Paquette JL (1987) Le métamorphisme éclogitique dans la nappe hercynienne de Champtoceaux (Massif armoricain). C R Acad Sci Paris 305:127-131

Bitri A, Ballèvre M, Brun JP, Chantraine J, Gapais D, Guennoc P, Gumiaux C, Truffert C (2003) Imagerie sismique de la zone de collision hercynienne dans le Sud-Est du Massif armoricain (projet Armor 2/programme Géofrance 3D). C R Geoscience 335:969-979

Blaise J, Cavet P, Lardeux H (1970) Les relations entre Briovérien et Paléozoïque sur la rive gauche de la Loire entre Saint-Florent-le-Vieil et Chalonnes (Maine-et-Loire, Sud-Est du Massif armoricain). Bull Soc géol Fr 7, 1:5-14

Bosse V, Feraud G, Ruffet g, Ballèvre M, Peucat JJ, De Jong K (2000) Late Devonian subduction and early-orogenic exhumation of eclogite-facies rocks from the Champtoceaux Complex (Variscan belt, France). Geol J 00:1-29

Bouchez JL, Blaise J (1976) Une structure hercynienne liée à un accident ductile : l'anticlinal de Lanvaux-les-Ponts-de-Cé, aux environs d'Angers (Massif Armoricain). Bull Soc géol Fr 7, XVIII: $145-157$

Bougault H, Joron JL, Treuil M (1980) The primordial chondritic nature and large scale heterogeneities in the mantle: evidence from high and low partition coefficient elements in oceanic basalts. Phil Trans R Soc London A 297:203-213

Cabanis B (1986) Identification des séries magmatiques dans les socles métamorphiques sur la base de critères géologiques, pétrographiques et géochimiques. Exemples d"application dans le Massif armoricain. Implications géodynamiques. Contribution à une méthode d'étude basée sur les éléments traces. Thèse d'Etat, Université Pierre et Marie Cury, Paris, pp 1-682

Cabanis B, Thiéblemont D (1988) La discrimination des tholéiites continentales et des basaltes arrière-arc. Proposition d"un nouveau diagramme, le triangle Th-3 x Tb-2 x Ta. Bull Soc géol Fr 8, IV:927-935

Carpenter M, Peucat JJ, Pivette B (1982) Geochemical and geochronological characteristics of Palaeozoic volcanism in the Saint-Georges-sur-Loire synclinorium (S. Armorican Massif). Evidence for pre-hercynian tectonic evolution. Bull Bur Rech Géol Min 21:63-79

Cartier C, Faure M, Lardeux H (2001) The Hercynian Orogeny in the South Armorican Massif (Saint-Georges-sur-Loire Unit, Ligerian Domain, France): rifting and welding of continental stripes. Terra Nova 13:143-149

Cartier C, Faure M, Lardeux H (2002) A new model for the Hercynian Orogen of Gondwana France and Iberia: a discussion. J Struc Geol 24:1,659-1,663

Cartier C, Faure M, Cocherie A and Lardeux H (2002) Evolution géodynamique du domaine ligérien (Massif Armoricain) au Paléozoïque. Abstract of Proceedings, 19ème Réunion des Sciences de la Terre, 98, C4:84 
Cavet P, Dubreuil M, Blaise J, Willefert S (1986) Les ampélites du Houx (Silurien), leurs relations avec les unités paléozoïques de Lanvaux-Les-Ponts-de-Cé et Saint-Georges-surLoire (Massif Armoricain). Bull Soc Sc Nat Ouest de la France 8:136-143

Cocherie A, Be Mezeme E, Legendre O, Fanning M, Faure M, Rossi P (2004) Electron microprobe dating as a tool for understanding closure of U-Th-Pb system in monazite from migmatite. American Mineralogist,

Cocks LRM (2000) The Early Palaeozoic geography of Europe. J Geol Soc London 157:1-10

Cogné J (1977) La chaîne hercynienne ouest-européenne correspond-elle à un orogène par collision? Propositions pour une interprétation géodynamique globale. Colloques internationaux du CNRS, 268 - Ecologie et géologie de l'Himalaya: 111-129

Diot H, Blaise J (1978) Etude structurale dans le Précambrien et le Paléozoïque de la partie méridionale du domaine ligérien (SE du Massif Armoricain): Mauges, synclinal d'Ancenis et Sillon Houiller de basse Loire. Bull Soc Géol Minér Bretagne C, X: 31-50

Dubreuil M (1986) Evolution géodynamique du Paléozoïque Ligérien (Massif Armoricain), Thèse d'Etat, Université de Nantes, pp 1-258

Faure M, Leloix C, Roig JY (1997) L'évolution polycyclique de la chaîne hercynienne. Bull Soc géol Fr 168:695-705

Faure M, Cartier C (1998) Déformations ductiles polyphasées dans l'antiforme orthogneissique de St-Clément-de-la-Place (unité de Lanvaux, Massif armoricain). C R Acad Sci Paris 326:795-802

Janjou D, avec la collaboration de Gruet M, Penecki C (1998) Carte Géol. France (1/50,000), feuille de Segré (422) — Orléans: Bureau de recherches géologiques et minières. Notice explicative par Janjou D et coll (1998), pp 68

Lardeux H (1967) Présence du Dévonien inférieur dans le synclinal de Saint-Georges-surLoire (Massif Armoricain, Anjou). C R Somm Soc géol Fr: 341

Lardeux H (1969) Le Dévonien du synclinal de Saint-Julien-de-Vouvantes (Sud-Est du Massif armoricain). Etat des recherches et précisions nouvelles. Bull Soc ét Sci Anjou VII, pp $3-40$

Lardeux H, Cavet P (1994). Paleozoic of the ligerian domain. In: Keppie JD (ed). PreMesozoic Geology in France and related areas. Springer, Berlin Heidelberg New York, pp $152-156$

Ledru P, Marot A, Herrouin Y (1986) Le synclinorium de Saint-Georges-sur-Loire: une unité ligérienne charriée sur le domaine centre armoricain. Découverte de métabasite à glaucophane sur la bordure de cette unité. C R Acad Sci Paris 303:963-968

Lys M, Mauvier A (1967) Résultats micropaléontologiques (conodontes) dans le Silurien et le Dévonien inférieur de l'Anjou. In: BRGM (ed). Mémoires du BRGM 33, Orléans, pp 59-60 
Marchand J (1981) Ecaillage d"un "mélange tectonique" profond: le complexe cristallophyllien de Champtoceaux (Bretagne Méridionale). C R Acad Sci Paris 293:223-228

Matte P (1986) La chaîne varisque parmi les chaînes paléozoïques péri-atlantiques, modèle d" évolution et position des grands blocs continentaux au Permo-Carbonifère. Bull Soc géol Fr 8:9-24

Matte P (2001) The Variscan collage and orogeny (480-290 Ma) and the tectonic definition of the Armorica microplate: a review. Terra Nova 13:122-128

Paris F, Robardet M (1990) Early Palaeozoic paleobiogeography of the variscan regions. Tectonophysics

177:193-213

Paris F (1998) Early Palaezoic palaeobiogeography of northern Gondwana regions. Acta Universitatis Carolinae-Geologica 42(3/4):473-483

Philippot A (1950) Les Graptolites du Massif Armoricain. Etude stratigraphique et paléontologique. Mém Soc géol Minéral Bretagne VIII, Rennes, pp 1-295

Pin C (1990) Variscan oceans: Ages, origins and geodynamic implications inferred from $\begin{array}{llll}\text { geochemical and } & \text { radiometric data. Tectonophysics }\end{array}$

Robardet M (2003) The Armorica "microplate": fact or fiction? Critical review of the concept and contradictory palaeobiogeographical data. Palaeogeography, Palaeoclimatology, Palaeoecology 195:125-148

Shelley D, Bossière G (2001) The Ancenis terrane: an exotic duplex in the Hercynian belt of Armorica, western France. J Struc Geol 23:1,597-1,614

Sun SS, McDonough WF (1989) Chemical and isotopic systematics of ocenaic basalts: implications for mantle composition and processes.In: Saunders AD, Norry MJ (eds). Magmatism in ocean basins. Geol Soc London Spec Publ 42, pp 313-345

Tait J, Schätz M, Bachtadse V, Soffel H (2000) Palaeomagnetism and Palaeozoic palaeogeography of Gondwana and European terranes. In: Franke W, Haak V, Oncken O, Tanner D (eds). Quantification and Modelling in the Variscan Belt. Geol Soc London Spec Publ 179, pp 21-34

Thiéblemont D, Cabanis B (1994) Magmatic Record of the Geodynamic Evolution of Brittany and Vendée During Palaeozoic Times: Trace Element Constraints. In: Keppie JD (ed). PreMesozoic Geology in France and related areas. Springer, Berlin Heidelberg New York, pp 220-230

Thiéblemont D, Guerrot C, Le Métour J, Jézéquel P (2001) Le complexe de Cholet-Thouars : un ensemble volcano-plutonique cambrien moyen au sein du bloc précambrien des Mauges. Géol fr 1-2, pp 7-17

Vachard D (1993) Algues, pseudo-algues et microfacies carbonatés du Dévonien du domaine Ligérien (Massif Armoricain, France). Palaeontographica Abteilung B: Palaeophytologie 229:53-113 
Vachard D (1994) Foraminifères et Moravamminidés du Givétien et du Frasnien du domaine Ligérien (Massif Armoricain, France). Palaeontographica Abteilung A: PalaezoologieStratigraphie 231:1-92

Vidal P (1980) L'évolution polyorogénique de Massif Armoricain : apport de la géochronologie et de la géochimie isotopique du strontium. Mém Soc géol Minéral Bretagne 21, Rennes, pp1-162 